ARTYKUŁY

Studenckie Zeszyty Naukowe 2019, Vol. XXII, nr 42

DOI: 10.17951/szn.2019.22.42.91-100

\author{
dr Malwina Ewa Kołodziejczak \\ Instytut Prawa i Administracji Obronnej \\ m.kolodziejczak@akademia.mil.pl
}

\title{
Wymiar prawny systemu kierowania bezpieczeństwem narodowym RP
}

\author{
Legal aspects of the national security management system \\ of the Republic of Poland
}

\section{STRESZCZENIE}

W polskim prawodawstwie nie ustanowiono jak do tej pory ustawy, która kompleksowo regulowałaby organizację i funkcjonowanie systemu bezpieczeństwa narodowego czy też - wężej-systemu kierowania bezpieczeństwem narodowym RP. Nie oznacza to jednak, że system kierowania nie funkcjonuje (albo przynajmniej jego elementy). Trudno jednak wskazać istnienie systemu nadrzędnego. Dlatego w niniejszym artykule przedstawione zostaną aspekty prawne systemu kierowania bezpieczeństwem narodowym RP, które są rozproszone w kilkunastu aktach prawnych. dowym

Słowa klucze: system bezpieczeństwa narodowego; system kierowania bezpieczeństwem naro-

\section{WPROWADZENIE}

Koncepcyjne próby stworzenia systemu kierowania bezpieczeństwem narodowym i szerzej systemu bezpieczeństwa narodowego były podejmowane przez ostatnie trzy dekady. Nadal jednak nie stworzono całościowych ram prawnych, które kompleksowo - w jednej ustawie - regulowałyby tę kwestię. Dlatego też problem główny niniejszego artykułu zawiera się w pytaniu: Jaka występuje organizacja i jaki jest obecny stan prawny systemu kierowania bezpieczeństwem narodowym? Celem jest scharakteryzowanie stanu prawnego systemu kierowania bezpieczeństwem narodowym. Hipoteza z kolei sprowadza się do przypuszczenia, że obecna organizacja systemu kierowania bezpieczeństwem narodowym RP nie zapewnia jego sprawnego funkcjonowania, gdyż brak spójnych, całościowych 
i kompleksowych regulacji prawnych, które przede wszystkim - ustanawiałaby ten system i pozwalały na jego prawidłowe funkcjonowanie zarówno pod względem prawnym jak i organizacyjnym. Jednocześnie, istnieją rozwiązania teoretyczne, które, jak się wydaje, z powodzeniem można by było wdrożyć na gruncie prawnym.

Jak zauważa Waldemar Kitler, ,świadome zachowanie się władz państwa i społeczeństwa, zmierzające do tworzenia bezpieczeństwa oraz wykorzystania w tym celu określonego potencjału, podobnie jak każde z działań złożonych, wymaga podejścia całościowego, ujęcia systemowego"1. W polskim prawodawstwie nie ustanowiono - jak do tej pory ustawy, która kompleksowo regulowałaby organizację i funkcjonowanie systemu bezpieczeństwa narodowego czy też systemu kierowania bezpieczeństwem narodowym. Nie oznacza to jednak, że system kierowania nie funkcjonuje (albo jego elementy). Trudno jednak wskazać istnienie systemu nadrzędnego. Dlatego w niniejszym artykule przedstawione zostaną aspekty prawne systemu kierowania bezpieczeństwem narodowym RP, które są rozproszone w kilkunastu aktach prawnych.

Ryszard Wróblewski już w 2000 roku stwierdził, że „bezpieczeństwo narodowe może być zapewnione tylko pod warunkiem istnienia spójnego i jednolitego systemu kierowania obroną państwa i w sytuacjach kryzysowych"2. Wyszczególnił on również zasady, według których należałoby zapewnić skuteczność funkcjonowania tego systemu. Zasady te wskazują na: jednoosobowe kierownictwo (na każdym szczeblu kierowania), powszechność, odpowiedzialność organów władzy publicznej, połączenie wysiłków przy jednoczesnej hierarchizacji działań, adekwatność zadań związanych z przeciwdziałaniem zagrożeniom w stosunku do charakteru i rozmiaru zagrożeń ${ }^{3}$. Pokrywa się to $\mathrm{z}$ wielokrotnie już wyrażonymi postulatami, rekomendacjami i wnioskami zawartymi w dokumentach strategicznych, gdzie wskazuje się na potrzebę regulacji prawnych, które łączyłyby działania z zakresu obronności i zarządzania kryzysowego w jeden spójny system kierowania bezpieczeństwem narodowym RP.

Należy stwierdzić, że zasadniczą formą organizacji i funkcjonowania systemu kierowania bezpieczeństwem narodowym pozostaje system bezpieczeństwa narodowego, dla którego zasadniczą formą organizacji i funkcjonowania pozostaje system obronny państwa. Co więcej, system bezpieczeństwa narodowego jest obiektem złożonym z wzajemnie powiązanych podsystemów, w tym systemu kierowania bezpieczeństwem narodowym oraz jest systemem nadrzędnym w stosunku do tego systemu.

1 W. Kitler, Bezpieczeństwo narodowe RP. Podstawowe kategorie. Uwarunkowania. System, Wyd. AON, Warszawa 2011, s. 313.

2 R. Wróblewski, System kierowania obroną państwa i zarządzania w sytuacjach kryzysowych, „Myśl Wojskowa”, Rocznik LXXXII, nr 4, lipiec-sierpień, MON, Warszawa 2000, s. 68.

3 W. Kitler, Bezpieczeństwo narodowe RP..., op. cit., s. 313. 
Podstawą funkcjonowania każdego państwa są normy regulujące i organizujące ustrój, działalność aparatu władzy i jego organy oraz system polityczny. Toteż, elementy te odgrywają istotną rolę w zakresie kształtowania systemu kierowania bezpieczeństwem narodowym. Podstawy te znalazły wyraz już w art. 5 Konstytucji RP, gdzie wyrażono expressis verbis najważniejsze zadania Rzeczypospolitej Polskiej, na których, jak można stwierdzić, opierają się poszczególne dziedziny bezpieczeństwa narodowego ${ }^{4}$.

Od kilku lat trwają prace nad wdrożeniem ustawy, która ustanawiałaby system bezpieczeństwa narodowego, w którym można byłoby wyróżnić system kierowania bezpieczeństwem narodowym. Na brak jednolitej podstawy prawnej, brak kompleksowego uregulowania i przede wszystkim brak spójności systemu wskazuje się od kilkunastu już lat.

Warto także wskazać, że także w dokumentach strategicznych wskazuje się wprost na brak regulacji prawnych, ustanawiających system bezpieczeństwa narodowego ${ }^{5}$. Co więcej, w Biatej Księdze podkreślono potrzebę włączenia zasad funkcjonowania systemu kierowania bezpieczeństwem narodowym do materii ustawowej. Wskazywano, że to w takiej ustawie powinny znaleźć się regulacje dotyczące: roli i zadań władz - szczególnie władzy wykonawczej i instytucji, kompetencji prezydenta i Rady Ministrów, zasad współpracy poszczególnych organów we wszystkich warunkach funkcjonowania państwa ${ }^{6}$. Jak wskazuje się także w Strategii rozwoju systemu bezpieczeństwa to system obronny państwa pozostaje zasadniczą formą organizacji i funkcjonowania zgodnie $\mathrm{z}$ art. 5 Konstytucji $\mathrm{RP}, \mathrm{a}, \mathrm{w}$ sensie prawnym system bezpieczeństwa narodowego nie stanowi zatem, funkcjonującej samodzielnie struktury państwowej"’ .

System bezpieczeństwa narodowego, ale także system kierowania bezpieczeństwem narodowym regulowany jest częściowo i nie wprost w licznych aktach

4 „Rzeczypospolita Polska strzeże niepodległości i nienaruszalności swojego terytorium, zapewnia wolności i prawa człowieka i obywatela oraz bezpieczeństwo obywateli, strzeże dziedzictwa narodowego oraz zapewnia ochronę środowiska, kierując się zasadą zrównoważonego rozwoju”, Konstytucja Rzeczypospolitej Polskiej z dnia 2 kwietnia 1997 r. (Dz. U. z 1997 r. Nr 78, poz. 483)., art. 5.

5 „Polskie prawo nie reguluje kompleksowo funkcjonowania systemu bezpieczeństwa narodowego. Brak unormowania organizacji i funkcjonowania systemu bezpieczeństwa narodowego w jednym akcie prawnym sprawia, że działania podejmowane w tym obszarze przez podmioty odpowiedzialne za poszczególne obszary bezpieczeństwa państwa mają często charakter sektorowy i rozproszony. Podejmowane dotychczas działania służące integracji wysiłków podmiotów odpowiedzialnych za bezpieczeństwo narodowe wypełniały najpoważniejsze luki, lecz nie wprowadzały systemowych i kompleksowych rozwiązań w skali państwa”. Vide: Strategia rozwoju systemu bezpieczeństwa Rzeczypospolitej Polskiej 2022, przyjęta uchwałą nr 67 Rady Ministrów z dnia 9 kwietnia 2013 r. (M.P. poz. 377)..., s. 14.

6 Biała Księga Bezpieczeństwa Narodowego Rzeczypospolitej Polskiej, Biuro Bezpieczeństwa Narodowego, Warszawa 2013, s. 201-202.

7 Strategia rozwoju systemu bezpieczeństwa..., s. 14-15. 
prawnych, wśród których najważniejsze to: ustawa o powszechnym obowiązu obrony Rzeczypospolitej Polskiej ${ }^{8}$, o zarzadzaniu kryzysowym ${ }^{9}$, o stanie wojennym ${ }^{10}$, o stanie wyjątkowym ${ }^{11}$ oraz o stanie klęski żywiołowej ${ }^{12}$. Co więcej, ,obowiązujący obecnie system prawny, obejmujący swoim zakresem regulacji dziedzinę obronną, dotyczy również systemu obronnego państwa, ma swoje źródło w innych realiach, działa według innych zasad i kryteriów. Ostatnie 20 lat to czas dynamicznych zmian, wywierających bezpośredni wpływ na środowisko bezpieczeństwa, skutkujących koniecznością częstego modyfikowania rozwiązań dotyczących tej dziedziny"13. A przecież rozpatrując bezpieczeństwo w ujęciu horyzontalnym należałoby także zwrócić uwagę na istniejące już ,regulacje prawne sankcjonujące funkcjonowanie szczegółowych systemów bezpieczeństwa w ogóle, m.in. systemów: obronnego państwa; ochrony granicy państwowej; ochrony informacji niejawnych; ochrony państwa i porządku konstytucyjnego; ochrony przeciwpożarowej; zintegrowanego zarządzania granicą państwową; ratowniczo-gaśniczy; Państwowe Ratownictwo Medyczne; ochrony danych osobowych" ${ }^{14}$, które także należałoby włączyć w zakres działania systemu kierowania bezpieczeństwem narodowym. Dlatego należy zwrócić uwagę na ustawę z dnia 26 kwietnia 2007 r. o zarządzaniu kryzysowym. W ustawie tej zarządzanie kryzysowe określone jest jako działalność organów administracji publicznej, która jest elementem kierowania bezpieczeństwem narodowym i polega na zapobieganiu sytuacjom kryzysowym, przygotowaniu do przejmowania nad nimi kontroli w drodze zaplanowanych działań, reagowaniu w przypadku wystąpienia sytuacji kryzysowych, usuwaniu ich skutków oraz odtwarzaniu zasobów i infrastruktury krytycznej ${ }^{15}$. Warto także przeanalizować definicję sytuacji kryzysowej, która w poprzedniej wersji ustawy określana była jako „sytuacja będącą następstwem zagrożenia i prowadząca w konsekwencji do zerwania lub znacznego naruszenia więzów społecznych przy równoczesnym poważnym zakłó-

8 Ustawa z dnia 21 listopada 1967 r. o powszechnym obowiązku obrony Rzeczypospolitej Polskiej (Dz. U. z 2017 r. poz. 1430).

9 Ustawa z dnia 26 kwietnia 2007 r. o zarządzaniu kryzysowym (Dz. U. z 2017 r. poz. 209 i 1566).

10 Ustawa z dnia 29 sierpnia 2002 r. o stanie wojennym oraz o kompetencjach Naczelnego Dowódcy Sił Zbrojnych i zasadach jego podległości konstytucyjnym organom Rzeczypospolitej Polskiej (Dz. U. z 2017 r. poz. 1932).

11 Ustawa z dnia 21 czerwca 2002 r. o stanie wyjątkowym (Dz. U. z 2017 r. poz. 1928).

12 Ustawa z dnia 18 kwietnia 2002 r. o stanie klęski żywiołowej (Dz. U. z 2017 r. poz. 1897).

13 W. Kitler, Systemy operacyjne bezpieczeństwa RP - aspekty prawne, [w:] Aspekty prawne bezpieczeństwa narodowego RP. Część ogólna, red. W. Kitler, M. Czuryk, M. Karpiuk, Wyd. AON, Warszawa 2013, s. 65.

14 Idem, Organizacja bezpieczeństwa narodowego RP - zasadnicze wnioski z diagnozy obecnego stanu rzeczy, [w:] System bezpieczeństwa narodowego RP. Wybrane problemy, red. nauk. W. Kitler, K. Drabik, I. Szostek, Wyd. AON, Warszawa 2014, s. 19-20.

15 Ustawa z dnia 26 kwietnia 2007 r. o zarządzaniu kryzysowym..., art. 2. 
ceniu w funkcjonowaniu instytucji publicznych, jednak w takim stopniu, że użyte środki niezbędne do zapewnienia lub przywrócenia bezpieczeństwa nie uzasadniają wprowadzenia żadnego ze stanów nadzwyczajnych, o których mowa w art. 228 ust. 1 Konstytucji Rzeczypospolitej Polskiej" ${ }^{\prime 6}$. Co interesujące, po ostatniej nowelizacji sytuację kryzysową rozumie się inaczej - jako sytuację wpływającą negatywnie na poziom bezpieczeństwa ludzi, mienia w znacznych rozmiarach lub środowiska, wywołującą znaczne ograniczenia w działaniu właściwych organów administracji publicznej ze względu na nieadekwatność posiadanych sił i środków ${ }^{17}$. Jakkolwiek krytycznie można podchodzić do regulacji dotyczących stanów nadzwyczajnych, poprzednia definicja wydaje się bardziej jasna i wskazująca wprost granicę ewentualnego rozważenia wprowadzenia stanów nadzwyczajnych. Już wtedy jednak pojawiały się wątpliwości dotyczące kompetencji poszczególnych organów wynikające z tej ustawy oraz z ustaw dotyczących stanów nadzwyczajnych, w sytuacji gdyby była konieczność uruchomienia określonych procedur. Obecnie, wydaje się, że granica między sytuacją kryzysową a koniecznością wprowadzenia któregoś ze stanów jest minimalna. Zakładając, że posiadane siły i środki uznane zostaną za nieadekwatne, czyli niewystarczające pojawia się już przesłanka wprowadzenia któregoś ze stanów nadzwyczajnych. Być może nie było potrzeby wskazywania na nieadekwatność środków. Na pewno jednak, nie będzie potrzeby ani też podstaw prawnych do mianowania Naczelnego Dowódcy Sił Zbrojnych.

W ustawie z dnia 21 listopada 1967 r. o powszechnym obowiązu obrony... wskazano, że do zadań Rady Ministrów należy przygotowywanie systemu kierowania bezpieczeństwem narodowym (w tym obroną państwa) i organów władzy publicznej do funkcjonowania na stanowiskach kierowania ${ }^{18}$. W związku z tym Rada Ministrów zobowiązana jest określić w drodze rozporządzenia organizację i tryb przygotowania systemu kierowania bezpieczeństwem narodowym, w tym obroną państwa, oraz warunki funkcjonowania organów władzy publicznej na stanowiskach kierowania ${ }^{19}$.

Toteż, mimo że nie istnieje ustawa regulująca system nadrzędny, system kierowania bezpieczeństwem narodowym został uregulowany $\mathrm{w}$ formie rozporządzenia $^{20}$. Co ważne, rozporządzenie to nie jest aktem wykonawczym do ustawy o zarządzaniu kryzysowym czy do którejś ustawy o stanach nadzwyczajnych, lecz do ustawy o powszechnym obowiązku obrony. Sam akt nie reguluje kompleksowo

${ }^{16}$ Ustawa z dnia 26 kwietnia 2007 r. o zarządzaniu kryzysowym, art. 3 pkt 1, (Dz. U. z 2007 r. nr 89, poz. 590).

17 Ustawa z dnia 26 kwietnia 2007 r. o zarządzaniu kryzysowym..., art. 3 pkt 1, (Dz. U. z 2017 r. poz. 209).

18 Ustawa z dnia 21 listopada 1967 r. o powszechnym obowiązku obrony..., art. 6 ust. 1 pkt 3.

19 Ibidem, art. 6 ust. 2 pkt 2.

20 Rozporządzenie Rady Ministrów z dnia 27 kwietnia 2004 r. w sprawie przygotowania systemu kierowania bezpieczeństwem narodowym (Dz. U. z 2004 r. Nr 98, poz. 978). 
zagadnienia, a jedynie, co zresztą zaznaczono w $\S 1$ określa organizację i tryb przygotowania tego systemu (w tym także obroną państwa ${ }^{21}$ ) oraz warunki funkcjonowania organów władzy publicznej na stanowiskach kierowania. I zdecydowanie skupia się bardziej na tym drugim zagadnieniu. Co istotne, w rozporządzeniu tym nie znalazła się definicja legalna ani systemu, ani tym bardziej systemu kierowania bezpieczeństwem narodowym. W $\S 2$ stwierdzono, że w skład systemu wchodzą organy władzy publicznej i kierownicy jednostek organizacyjnych, a także organy dowodzenia Siłami Zbrojnymi Rzeczypospolitej Polskiej, w tym Naczelny Dowódca Sił Zbrojnych, z chwilą jego mianowania. Dalej wskazano, że organy te uczestniczą w kierowaniu bezpieczeństwem oraz wykonują zadania w ramach swoich kompetencji, biorąc pod uwagę skalę zagrożenia. Dodano także, że system kierowania przygotowuje się celem zapewnienia ciągłości podejmowania decyzji i działań. W ramach tychże działań wyróżniono monitorowanie zagrożeń oraz zapobieganie ich powstawaniu i ewentualnym skutkom ich wystąpienia oraz kierowanie obroną państwa ${ }^{22}$. Przy czym przygotowanie dotyczy planowania, organizowania i realizowania działań, które zapewnić mają poszczególnym organom wykonanie zadań nie tylko w czasie pokoju, lecz także „w razie wewnętrznego lub zewnętrznego zagrożenia bezpieczeństwa narodowego, w tym w razie wystąpienia działań terrorystycznych lub innych szczególnych zdarzeń, a także w czasie wojny"23. Podkreślić zatem należy, że rozporządzenie jest szczególnie istotne także w przypadku wprowadzenia, któregoś ze stanów nadzwyczajnych, ale również i w czasie normalnego funkcjonowania państwa. A zatem przedsięwzięcia te realizuje się w czasie pokoju. I tu pojawia się dość istotny problem. Zdecydowana większość zadań związanych z przygotowaniem systemu kierowania bezpieczeństwem narodowym dotyczy działań wykonywanych w czasie pokoju. Jednak w czasie pokoju Naczelny Dowódca nie funkcjonuje. W związku z tym, Naczelny Dowódca zgodnie z niniejszym rozporządzeniem nie powinien brać w nich udziału. Biorąc pod uwagę ostatnie zmiany wprowadzające kandydata na Naczelnego Dowódcę, należałoby również dostosować i to, jakże ważne rozporządzenie.

W rozporządzeniu uregulowano także kwestię przygotowania głównych stanowisk kierowania dla prezydenta, Rady Ministrów, ale także dla prezesa Rady Ministrów, poszczególnych ministrów oraz kierowników urzędów centralnych

21 Czyli nie tylko dotyczy sytuacji związanej z kierowaniem obroną państwa, co z kolei oznacza, że zakres przedmiotowy rozporządzenia wydaje się wykraczać poza zakres przedmiotowy aktu nadrzędnego - ustawy o powszechnym obowiązku obrony.

22 Rozporządzenie Rady Ministrów z dnia 27 kwietnia 2004 r. w sprawie przygotowania systemu kierowania..., 3 .

23 Ibidem, § 4 ust. 2 „Przedsięwzięcia, o których mowa w ust. 1, obejmują:

${ }^{1)}$ przygotowanie organów i obsługujących ich urzędów do funkcjonowania w systemie kierowania;

${ }^{2)}$ wykonywanie planów operacyjnych i programów obronnych;

${ }^{3)}$ przygotowanie infrastruktury umożliwiającej funkcjonowanie systemu kierowania. 
i zespolonych służb, inspekcji i straży oraz organów wykonawczych samorządu terytorialnego. Nie wspomina się jednak o stanowisku kierowania dla Naczelnego Dowódcy Sił Zbrojnych ${ }^{24}$. Jest to po części zrozumiałe, gdyż w obecnych przepisach prawnych, za przygotowania stanowiska dowodzenia (co koresponduje z kierowaniem), odpowiada Dowódca Operacyjny Rodzajów Sił Zbrojnych ${ }^{25}$.

W Białej Księdze stwierdzono, że „na kierowanie bezpieczeństwem narodowym składają się trzy podstawowe elementy: kierowanie obroną państwa (właściwość prezydenta RP we współdziałaniu z Radą Ministrów), sprawowanie ogólnego kierownictwa w zakresie obronności (właściwość Rady Ministrów) oraz zarządzanie kryzysowe (właściwość Rady Ministrów, wojewodów, starostów, wójtów, burmistrzów i prezydentów miast)"26. Mimo że nie do końca można zgodzić się z takim ujęciem podziału, z pewnością należy zauważyć wiodącą rolę władzy wykonawczej na każdym poziomie struktury terytorialnej - także samorządowej. Jak stwierdza Waldemar Kitler: „organy władzy wykonawczej odgrywają zasadniczą rolę w zapewnieniu bezpieczeństwa $\mathrm{z}$ uwagi na posiadanie formalnego mandatu do: stanowienia prawa państwowego, zarządzania państwem, kontroli przestrzegania reguł prawnych oraz egzekwowania swoistego przymusu państwowego w stosunku do wszystkich podmiotów systemu politycznego"27.

Mimo pewnego postępu w budowaniu relacji związanych z funkcjonowaniem poszczególnych organów w systemie kierowania bezpieczeństwem narodowym nadal występują problematyczne treści przepisów formułujących zadania Prezydenta RP oraz rządu na czele z premierem. Nadmienić należy, że poprzez ciągłe i wielokrotne nowelizacje przepisów, brak usystematyzowania, uporządkowania i wskazania konkretnych kompetencji powyższych organów, nadal występują problemy natury tak prawnej jak i organizacyjnej.

Należy podkreślić, że mimo braku ustawowej regulacji dotyczącej systemu kierowania bezpieczeństwem narodowym czy szerzej - systemu bezpieczeństwa narodowego, system, a raczej elementy, misje i relacje go tworzące funkcjonują. Jednak zgodnie z obowiązującymi przepisami system kierowania bezpieczeństwem narodowym postrzegany jest jako część systemu obrony państwa, co biorąc pod uwagę zarówno definicję bezpieczeństwa narodowego, jak i zakres przedmiotowy ujęty jedynie w rozporządzeniu umiejscowienie to okazuje się niewystarczające. Na wszystkich szczeblach kierowania systemem bezpieczeństwa narodowego konieczne jest zintegrowanie, hierarchiczne zorganizowanie, sprawne funkcjo-

24 Ibidem, § 11.

25 Wydaje się jednak, że po reformie systemu kierowania i dowodzenia z powrotem zadanie to będzie należało do Szefa Sztabu Generalnego WP. Vide: ustawa z dnia 21 listopada 1967 r. o powszechnym obowiązku obrony..., art. $11 \mathrm{~b}$ ust. 2 pkt 5 .

26 Biała Księga..., s. 37.

27 W. Kitler, Bezpieczeństwo narodowe RP..., op. cit., s. 335. 
nowanie, wyodrębnienie zadań poszczególnych organów oraz przede wszystkim skodyfikowanie dotychczasowych przepisów najlepiej w jednej spójnej ustawie.

Jak stwierdza Natalia Moch: „w świetle prawa powszechnie obowiązującego można wysnuć więc wniosek, iż system kierowania bezpieczeństwem narodowym jest częścią systemu obronnego państwa, co oznacza, że powinien realizować zadania jedynie w zakresie ochrony żywotnych interesów Rzeczypospolitej Polskiej"28.

Jak wskazał Waldemar Kitler na podstawie syntezy dokumentów strategicznych, „,budowa zintegrowanego SBN w Polsce realizowana być powinna w oparciu o już funkcjonujący SOP oraz dodatkowo o SZK, z wykorzystaniem innych systemów i podmiotów, poprzez ustanowienie ich elementami SBN, określenie ich zadań na rzecz bezpieczeństwa narodowego, ustanowienie relacji systemowych, a także określenie: procedur implementacji rozwiązań systemowych, funkcjonowania i doskonalenia systemu"29.

$$
* * *
$$

Podkreślenia wymaga fakt, że nie ma ustawy tworzącej system bezpieczeństwa narodowego. Przepisy odnoszące się do tego systemu są rozproszone, co powoduje jego niespójność, różnice w interpretacji przy określaniu zakresu zadań poszczególnych organów, a przede wszystkim, brak tak istotnej pewności prawa. Co wynika także z częściowego braku definicji legalnych. Co prawda, część wyrażeń i pojęć znalazła rozwinięcie w dokumentach strategicznych czy aktach prawa wewnętrznie obowiązujących, jednak nie mogą one prowadzić do jednolitej interpretacji poszczególnych terminów.

Część zagadnienia systemu kierowania bezpieczeństwem narodowym reguluje ustawa z dnia 21 listopada 1967 r. o powszechnym obowiazku obrony, ale tylko w pewnym zakresie, przy czym nie uwzględniono przepisów z zakresu zarządzania kryzysowego, mimo że rozporządzenie nawiązuje do tej materii. Tym samym dotyczy sytuacji związanej z nie tylko kierowaniem obroną państwa, co z kolei oznacza, że zakres przedmiotowy rozporządzenia wydaje się wykraczać poza zakres przedmiotowy aktu nadrzędnego - ustawy o powszechnym obowiązku obrony. Oznacza to, że system kierowania bezpieczeństwem narodowym także uregulowany i zorganizowany jest w sposób niewystarczający. Należy stwierdzić, że rozporządzenia nie mają wystarczającej mocy prawnej, by regulować istotę kierowania bezpieczeństwem narodowym. Wydaje się zatem, że postulat potrzeby ujednolicenia przepisów, całościowej regulacji, a przede wszystkim, zastosowania

28 N. Moch, Kierowanie obroną narodową w systemie kierowania bezpieczeństwem narodowym Rzeczypospolitej Polskiej, Rozprawa doktorska, AON, Warszawa 2014.

29 W. Kitler, Koncepcja systemu bezpieczeństwa narodowego Rzeczypospolitej Polskiej, Praca nauk.-bad., WBN, AON, Warszawa 2013, s. 23. 
rozwiązań, które unormowane byłyby w aktach prawa powszechnie obowiązującego jest nadal aktualny. Dlatego należy zwrócić uwagę na brak zdecydowanych ruchów decydentów politycznych, którzy - jak do tej pory - nie zdecydowali w formie aktu ustawowego jaką rolę powinien odgrywać system kierowania bezpieczeństwem narodowym.

Koniecznym wydaje się także zwrócenie uwagi, że w przywoływanych dokumentach strategicznych jak i w rozporządzeniu dotyczącym systemu kierowania bezpieczeństwem narodowym, system ten rozumiany jest, co do zasady, bardzo szeroko. Pierwotne, wynikające z zakresu nauk o zarządzaniu, cechy kierowania (takie jak planowanie, organizowanie, kierowanie), zyskały o wiele szersze zastosowanie, gdyż w ramach tego systemu prowadzone działania miałyby dotyczyć także monitorowania, rozpoznawania czy zapobiegania ${ }^{30}$.

W kontekście poczynionych badań, wspomnieć także należy o Strategicznym Przegladzie Obronnym ${ }^{31}$, którego wyniki przedstawiono jak do tej pory, w Koncepcji obronnej Rzeczypospolitej Polskiej ${ }^{32}$. Najważniejsze ustalenia w zakresie kierowania sprowadzają się do zapowiadanych zmian systemu poprzez jego uproszczenie, jasne wskazanie i przydzielenie zadań oraz odpowiedzialności za ich wykonanie, hierarchiczność oraz jednoznaczne wskazanie najwyższego rangą dowódcy. Finalnie jednak powstać ma jedna, kompleksowa ustawa regulująca zagadnienia związane z kierowaniem obroną państwa.

\section{BIBLIOGRAFIA}

Aspekty prawne bezpieczeństwa narodowego RP. Część ogólna, red. W. Kitler, M. Czuryk, M. Karpiuk, Wyd. AON, Warszawa 2013.

Biała Księga Bezpieczeństwa Narodowego Rzeczypospolitej Polskiej, Biuro Bezpieczeństwa Narodowego, Warszawa 2013.

Kitler W, Bezpieczeństwo narodowe RP. Podstawowe kategorie. Uwarunkowania. System, Wyd. AON, Warszawa 2011.

Kitler W., Koncepcja systemu bezpieczeństwa narodowego Rzeczypospolitej Polskiej, Praca nauk. -bad., WBN, AON, Warszawa 2013.

${ }_{30}$ Vide: opis systemu kierowania bezpieczeństwem narodowym w Biała Księga, Strategii rozwoju bezpieczeństwa..., rozporządzeniu Rady Ministrów z dnia 27 kwietnia 2004 r. w sprawie przygotowania systemu kierowania...

31 Autorka miała okazję brać udział w opracowaniu przygotowanym przez zespół Akademii Obrony Narodowej na potrzeby Strategicznego Przeglądu Obronnego, w którym przygotowała treść punktu 3.2 w rozdziale: Organizacja i funkcjonowanie systemu kierowania i dowodzenia Siłami Zbrojnymi RP w poszczególnych stanach gotowości obronnej państwa w aspekcie formalno-prawnym. Część wyników analizy poczynionej na potrzeby tego tematu zostanie ujęta w rozdziale właściwym o Naczelnym Dowódcy oraz w rozdziale koncepcyjnym.

32 Koncepcja obronna Rzeczypospolitej Polskiej, MON, Warszawa, maj 2017, s. 51-53. 
Kitler W., Organizacja bezpieczeństwa narodowego RP - zasadnicze wnioski z diagnozy obecnego stanu rzeczy, [w:] System bezpieczeństwa narodowego RP. Wybrane problemy, red. nauk. W. Kitler, K. Drabik, I. Szostek, Wyd. AON, Warszawa 2014.

Koncepcja obronna Rzeczypospolitej Polskiej, MON, Warszawa, maj 2017.

Konstytucja Rzeczypospolitej Polskiej z dnia 2 kwietnia 1997 r. (Dz. U. z 1997 r. Nr 78, poz. 483).

Moch N., Kierowanie obrona narodowa w systemie kierowania bezpieczeństwem narodowym Rzeczypospolitej Polskiej, Rozprawa doktorska, AON, Warszawa 2014.

Rozporządzenie Rady Ministrów z dnia 27 kwietnia 2004 r. w sprawie przygotowania systemu kierowania bezpieczeństwem narodowym (Dz. U. z 2004 r. Nr 98, poz. 978)

Strategia bezpieczeństwa narodowego Rzeczypospolitej Polskiej z 2014 roku, zatwierdzona na wniosek Prezesa Rady Ministrów przez Prezydenta RP 5 listopada 2014 roku.

Strategia rozwoju systemu bezpieczeństwa narodowego Rzeczypospolitej Polskiej 2022, przyjęta uchwałą nr 67 Rady Ministrów z dnia 9 kwietnia 2013 r. (M.P. poz. 377).

Strategii obronności - strategii sektorowej do Strategii bezpieczeństwa narodowego RP, Warszawa 2009.

Ustawa z dnia 21 listopada 1967 r. o powszechnym obowiqzku obrony Rzeczypospolitej Polskiej (Dz. U. z 2017 r. poz. 1430).

Ustawa z dnia 18 kwietnia 2002 r. o stanie klęski żywiołowej (Dz. U. z 2017 r. poz. 1897).

Ustawa z dnia 21 czerwca 2002 r. o stanie wyjątkowym (Dz. U. z 2017 r. poz. 1928).

Ustawa z dnia 26 kwietnia 2007 r. o zarzadzaniu kryzysowym..., (Dz. U. z 2017 r. poz. 209 i 1566).

Ustawa z dnia 26 kwietnia 2007 r. o zarządzaniu kryzysowym, (Dz. U. z 2007 r. nr 89, poz. 590).

Ustawa z dnia 29 sierpnia 2002 r. o stanie wojennym oraz o kompetencjach Naczelnego Dowódcy Sit Zbrojnych i zasadach jego podległości konstytucyjnym organom Rzeczypospolitej Polskiej (Dz. U. z 2017 r. poz. 1932).

Wróblewski R., System kierowania obrona państwa i zarzadzania w sytuacjach kryzysowych, „Myśl Wojskowa”, Rocznik LXXXII, nr 4, lipiec-sierpień, MON, Warszawa 2000.

\section{SUMMARY}

Nowadays, there is no legal rules in one statute that would comprehensively regulate the organization and functioning of the national security system, or - narrowly - the national security management system of the Republic of Poland. This does not mean, that the steering system does not function (or at least its elements). However, it is difficult to indicate the existence of one act in which the superior system would be regulated. Therefore, this article will present the legal aspects of the national security management system, which are dispersed in over a dozen legal acts.

Keywords: national security system, national security management system. 